\title{
Investigating The Impact Of Justice Dimension And Perceived Value On Customer Satisfaction For Sharing Economy Of Accommodation
}

Kim Bokyeong, KDI School of Public Policy and Management, South Korea Yoon C. Cho, KDI School of Public Policy and Management, South Korea

\begin{abstract}
The sharing economy is in the embryonic stage of its development, and empirical research has rarely studied issues in the sharing economy. This study examines the impacts of justice dimensions and perceived $v$ alues on intention, satisfaction, and loyalty in the context of the sharing economy. The purpose of the study is to examine the impact of procedural, interactional, and distributive justice dimensions of customers as well as perceived values of price, trust, and experiences on intention, satisfaction and loyalty for the sharing economy of accommodation. This study investigated the following research questions: i) how does the awareness of sharing economy affect the justice dimension that includes procedural justice, distributive justice, and interactional justice?; ii) how does the awareness of sharing economy affect perceived values including price, reliability, and experience?; iii) how do justice dimensions and perceived values affect potential customer intention?; iv) how do justice dimensions and perceived values affect customer satisfaction?; and v) how does customer satisfaction affect customer loyalty? This study collects data through an online survey and applies quantitative methods such as factor, regression, and ANOVA. The results find that both justice dimensions and perceived values play an essential role in improving satisfaction and loyalty. This study provides both theoretical and managerial implications for future analysis of the relationship between justice dimensions, perceived values, satisfaction, and loyalty in the environment of sharing economy of accommodation.
\end{abstract}

Keywords: Sharing Economy; Justice Dimension; Perceived Value; Intention; Customer Satisfaction; Loyalty

\section{INTRODUCTION}

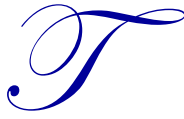

he capital society has been evolving from consumerist-based, where having ownership was its main concern to a hyper-consumption society that places emphasis more on time, experience, and opportunity than on possession in itself (Aquise, 2014). The term "sharing economy," coined by Lessig (Walsh, 2011), has become a new business platform that fundamentally changes the traditional business market (Cusumano, 2015). Belk (2007) describes the idea of sharing as the act and process of distributing what is ours to others for their use and/or the process of receiving or taking something from others for our utilization. The sharing economy not only breaks down the categories of all industry, but also maximizes the use of scarce res ources (Allen, 2014). As one of the remarkable characteristics of the sharing economy is to exchange focusing on access over ownership, the firms have been transformed into the facilitators of exchange rather than the producers (Allen, 2014). The sharing economy has been applied in most fields for tangible and intangible products and services, including accommodation, cars, space, money, knowledge, and skills by providing user-centered strategies. The sharing economy as an economic model based on sharing underutilized as sets from spaces to skills to stuff for nonmonetary or non-monetary benefits, largely focused on peer-to-peer (P2P) marketplaces" (Botsman, 2013). Key effective factors for sharing economy include maximization of satisfaction and loyalty (Masoodul, 2013; Dick \& Basu, 1994) for both sides including providers (i.e., supply) and users (i.e., demand). 
This study investigated the effect of justice dimensions and perceived values such as price, trust, and experience on intention, satisfaction and loyalty in the context of the sharing economy of accommodation. Justice dimensions are regarded as significant factors into determining customer satisfaction (Oliver \& Swan, 1989) and depicted as multidimensional elements of consumers' subjective evaluation of services and products (Blodg ett, Hill, and Tax, 1997; Adams, 1965). According to Vicente et al. (2006), customers have expectation of their experiences of consumption and evaluate the products and services through justice perceptions. These dimensions are regarded as the crucial factors in examining customer attitude, satisfaction, and loyalty (Seiders \& Berry, 1998; Goodwin \& Ross, 1992). In addition to the justice dimensions, the perceived values of customers have also been applied to the investigation of the strategic business management (Mizik \& Jacobson, 2003; Spiteri \& Dion, 2004). Price is considered as one of the elements that highly affect consumer behavior and satisfaction (Lichtenstein, Ridgway, and Netemeyer, 1993) Grewal, Monroe, \& Krishannan, 1998). Trust has been considered one of the factors that determine customer belief, attitude, expectation, and behavior (Andaleeb, 1992) and has become more important in the online environment, as it needs to manage the risk of interactions with individuals (Xiong \& Liu, 2002). Experience as one of the variables in perceived values could also affect the brand image of corporations (Nguyen \& Leblanc, 2001). Recent survey analysis (PwC, 2015) indicates that consumers are willing to use the service when they have unique and attractive experiences in the sharing economy.

The purpose of this study is to investigate how justice dimensions and perceived values affect customer intention, satisfaction, and loyalty. This study applied justice dimensions including procedural, interactional, and distributive fairness and perceived values including price, trust, and experience. Research questions in this study include the following for the sharing economy of accommodation: i) how does the awareness of the sharing economy affect justice dimension and perceived values?; ii) how do justice dimensions and perceived values affect customer intention and satisfaction?; and iii) how does customer satisfaction affect customer loyalty?

\section{LITERATURE REVIEW}

\subsection{The Sharing Economy}

The new frame of the sharing economy deeply influences the core business models of existing enterprises by combining social technologies and worldwide population growth (Benkler, 2004). The growth of the sharing economy was estimated at $25 \%$ in 2013, with over 3.5 billion in revenue (Forbes 2013). Based on the tragedy of the commons, Hardin (1968) and Benkler (2002) argue that people all act in their own selfish interests. People therefore pursue their own quality of life, so that they deplete the shared resources they need (Benkler, 2002). The basic concept of the sharing economy is to share people's needs or interests as well as to exchange fewer tangible assets such as time, space, skills, and money (Benkler, 2004). People use the web platforms that bring together individuals who have underutilized assets with people who are willing to share the assets short-term(Cusumano, 2015).

The characteristics of the sharing economy are driven by three separate market forces, including societal drivers, economic drivers, and technological drivers (Owyang, 2013). Rinne et al. (2013) points out that population growth continues to sharply rise with limited resources. By sharing the resources that they previously owned, people try to make a more sustainable and peaceful economy (Gansky, 2010). Gansky (2010) also notes that people want to be engaged in social networks. Starting from 2008, during the Global Recession, people fundamentally began to consider what values they want to pursue and which system makes people happier (Botsman, 2011). Sharing products and services precedes ownership, which was previously the superior concept in a capitalistic economy (Gansky, 2010). Furthermore, the most impactful Internet feature driving the sharing economy is the increasing ubiquity of social networking and real-time technologies (Botsman, 2010). According to Botsman (2010), the ubiquity of social networking and technologies is one of the most significant drivers in terms of the sharing economy. By using the social network system, all the processes between provider and consumer in the sharing business become very easy in terms of choosing the service and product at the right time and location (Gansky, 2010). Rinne et al. (2013) mentioned that the peer-to-peer (P2P) transaction model gives people a way to use the resources efficiently by matching supply and demand instantly. To safely establish the framework, it is also necessary to consider the various constraints of government, the legal system, and the remaining social issues on the sharing economy (Allen 2014). The Economist (2013) argues that a study of the consumer benefits and potential of the sharing economy should examine the sharing economy as a successfulbusiness model. 
Among the cases of sharing economy of accommodation, Airbnb is valued at 13 billion dollars, which is higher than its competitors such as Hyatt or Wyndham (PwC, 2015). Airbnb started in 2007 in San Francisco when the founders had an extra room to rent and decided to offer low-cost air mattres ses to attendees at a local conference (Cusumano, 2015). Approximately 40,000 people rented accommodations from a service that offers 250,000 rooms in 30,000 cities in 192 countries (http://www.airbnb.com, 2015). Technology developments such as the Internet and mobile technology have reduced transaction costs, making sharing assets much cheaper and easier than ever, therefore it becoming much larger scale (The Economist, 2014). Developed social networks also help consumers freely choose the products they want, and by using the services they build trust in the system (The Economist, 2013). As more and more people are interested in having unique experience with these services, online platforms such as Airbnb might be an appropriate business model to give the consumer a local flavor that is very attractive and different from any other hospitality services (PwC, 2015). It also has a few challenges from the government and legal issues in confronting the previous business models and systems (Allen, 2014).

\subsection{Justice Dimension}

Justice (Equity) theory has argued that people are usually motivated when they make a comparis on by the results that the consumer has received (Adams, 1965). Clemmer and Schneider (1996) mentioned that different justice dimensions are determinants of consumer satisfaction and loyalty. Cohen (2001) states that perceived justice is related to cognitive and behavioral reactions to outcome, and the outcome of using products or services could affect consumer emotions and behaviors. The sharing economy concept has been addressed with the considerations of justice such as human rights and social justice (https://www.opendemocracy.net). Previous research has suggested that the justice dimensions consist of three elements: procedural justice, interactional justice, and distributive justice (Seiders \& Berry, 1998; Goodwin \& Ross, 1992). Thibaut and Walker (1975) define procedural justice as the perception of the procedures for arriving at outcomes. Interactional justice is described as the customers' perception that they have experienced services and products with the appropriate level of respect and propriety treatment (Poole, 2007). Distributive justice is defined by Homans (1960) as the perception of outcome or decision of customers. In regard to the service justice theory, the three dimensions were identified as the perception of service regulation (procedural justice), service manner and its susceptibility (interactional justice), and monetary rewards (distributive justice) (Blodgett, Hill, \& Tax, 1997; Smith, Bolton, \& Wagner, 1999). Various studies have found that the justice dimensions significantly influence customer satisfaction and loyalty intentions (Chiu et al., 2009). Therefore, examining the relationship between justice dimensions of customers and their satisfaction is crucial for the new business platforms in the sharing economy.

Distributive justice based on equity theory, states that customers pursue their outcomes to maximize gains and minimize losses (Adams, 1965). Distributive justice is explained by the perceived equity of an outcome or a decision (Homans, 1961) and is also defined as the allocation of costs and benefits in terms of exchange relationships (Smith, Bolton, \& Wagner, 1999). Huppertz, Arenson and Evans (1978) focused on distributive justice in order to examine customer satisfaction. Previous studies define procedural justice as a principle that all the process and relevant policies in services should meet (Lind \& Tyler, 1988). Thibaut and Walker (1975) identified procedural justice as the perception of the procedures for arriving at outcomes. Consumers in general not only consider the outcomes they receive, but also expect fair processes (Goodwin \& Ross, 1989; Smith, Bolton, \& Wagner, 1999). In the context of service recoveries, procedural justice defines the customer perception of policies and procedures in the decisionmaking process (Blodgett, Hill, \& Tax, 1997). Smith, Bolton, \& Wagner (1999) also mentioned procedural justice as the customer's perception of the systematic process of the company in solving service problems or complaints. Procedural justice is one of the crucial elements in terms of strategic management (Maxham \& Netemeyer, 2002). Since procedural justice is particularly relevant service business strategies, this perception deals with issues of accessibility and promptness (Blodgett Hill, \& Tax, 1997; Tax, Brown, \& Chandrashekaran, 1998). In the sharing economy, with the growing number of digital services that make matching demand and supply, the usability of the process is unpredecented (https://www.pwc.com).

Interactional justice is the fairness of interpersonal treatment or informational processes that customers receive during the service experience (Blodgett Hill, \& Tax, 1997). In previous research, both procedural justice and interactional justice are connected to contemporary social exchange theories (Cropanzano, Rupp, Mohler, \& Schminke, 2001). Interactional justice also refers to the quality and perceived equity when individuals feel they have 
received the services and products with the appropriate level of respect and propriety treatment (Poole, 2007). In terms of interpersonal justice, it is held that individuals should be treated with the proper level of respect, sincerity, and courtesy (Maxham \& Netemeyer, 2002). According to previous research (https://www.pwc.com), deeper social interactions are crucial in the sharing economy business models. In terms of service management research, interactional justice is also one of the crucial factors to predicting customer satis faction and loyalty, particularly in the relationships of marketing approach (Grönroos, 1994).

\subsection{Perceived Value}

Perceived value is, in general, depicted as the overall assessment the usefulness based on consumer perceptions of what is received and what is given (Heinonen, 2004). Consumer perceived values are related to the attitude, satisfaction, and loyalty that also create business profits (Khalifa, 2004). Therefore, the consumer value has become the main issues handled by various marketing activities (Holbrook, 1994). Economically, value has been defined as a main factor of utility or desirability (Tellis \& Gaeth, 1990). Even though previous studies on perceived value have normally focused on monetary values such as price, it has recently moved to a broader construct than only the utility and price dimensions (Monroe, 1990; Zeithaml, 1988). Recent research, however, puts more importance on perceived value as a multi-dimensional construct, which deals with various interrelated dimensions (Holbrook, 1994; Babin, Darden, \& Griffin, 1994; Sheth, Newman, and Gross, 1991). The perceived consumer value has two significant dimensions of consumer behavior; one is the economic value linked to perceived price, and the other is the psychological value that influences the consumer's emotion (Gallarza \& Saura, 2006). The study examines the perceived values dividing the dimensions into price, trust, and experience values. Customer perception and satisfaction are closely connected, as customer expectation based on the service leads to satisfaction (Reichheld, 1996). Based on the above discussion of perceived value, this study explains the perceived values as independent variables affecting consumer attitude, satisfaction, and loyalty.

Jacoby and Olson (1977) depicted price as the perceptual representation of the customer, as well as its subjective perception of the objective price for the product. Consumers perceive the price of products or services to be high, low, or fair according to their internal standards (Gabor \& Granger, 1961; Monroe, 1990). Thus, consumers justify the price with reasonable consciousness and define price fairness (Xia, Monroe, \& Cox, 2004). Researchers that the price value is a crucial instrument for consumer behavior in dealing with satisfaction and trust (Lichtenstein, Ridgway, and Netemeyer, 1993; Grewal, Monroe, \& Krishannan, 1998). In recent studies of business management in online services, price is one of the major ways to attract consumers to shop online, showing that $85 \%$ of consumers search for price information when they shop online (Stewart \& Reed, 1999). Empirical findings from the research showed that perceived price is positively related to customer satisfaction and purchase intentions (Campbell, 1999; Campbell, 2007; Oliver \& Swan, 1989). Scholars have also stated that trust is one of the critically important factors in productive, cohesive functioning for individuals, communities, regions, and nations (Stolle, 2002). Measuring trust and satisfaction have been es sential elements for sustainable business relationships especially in e-commerce (Kim, Ferrin, \& Rao, 2003). In particular, a trusted process is a main factor in the context of online services (Grabosky, 2001). Bostman (2010) addressed that trust is one of key factors for the sharing economy.

Previous studies (Arnould \& Thomson, 2005; Holbrook \& Hirschman, 1982) have long focused on the effect of consumer experiences. These studies indicated that experience is connected with having authenticity (Rose \& Wood, 2005), socialization (John, 1999), and unique experience (Verhoef et al., 2009). In addition to that, there is considerable research based on experience such as self-identified experience (Wood, Chaplin, \& Soloman, 2000). Owyang (2013) finds that people think it is important to connect with communities and mentioned that the guests of a room-sharing service prefer the experience of staying in a home or neighborhood which gives different and more unique feeling than the other accommodation businesses. Experiences are the significant variables in regard to the perceived values to affect the brand image of corporations (Nguyen \& Leblanc, 2001). Also, recent survey analysis done by PwC (2015) stated that the consumers are willing to use a service offering unique and attractive experiences in the sharing economy. 


\section{THEORETICAL BACKGROUND}

Building upon the foundations of equity theory (Adams, 1965), Homans (1961) described that justice dimension is also the role of judgment for allocating rewards on the basis of individual contributions. Homans (1961) also mentioned that the relationship between individuals' reward in terms of exchange should be equal to their input or investment. The distributive justice is the perceived justice of the outcome or decision (Homans, 1961), while interactional justice is the dimension of perceived fairness of treatment in both interpersonal and informational aspects (Bies \& Moag, 1986). Procedural justice is the perceived dimension of the procedure in achieving the outcome (Thibaut \& Walker, 1975) with emphasis on the process, method, and rules that are used to determine the outcomes and the effect of fairness on those outcomes. (Thibaut \& Walker, 1975).

Aaker, Kumar, and Day (2001) described that customer intention is based on their attitude determined by their psychological conception of services or products. The conception of consumer attitude is firstly used by Lancaster (1966), defining the attitude of the consumer as the driver of their utility and attributes. Whitlar, Geurts and Swenson (1993) mentioned purchase intention as a purchase probability associated with the percentage of individuals that actually buy a product. Similarly, attitude has been discussed as a psychological construct and as a way of conceptualizing the intangible (Aaker, Kumar, \& Day, 2001). Ajzen and Fishbein (1980) state that human beings, in general, are quite rational and try to make systematic use of the information available to them. Arnould, Zinkhan, and Price (2002) focus on the definition of attitude as the overall evaluation of a service and products by the consumer. Recent studies of the intention to use online services (Burke, 1997; Peterson et al., 1997) showed that there are a few variables to examine in terms of consumer attitude such as convenience, price, and product categories. Ajzen and Fishbein (1980) stated that consumer behavior can be also explained by number of concepts such as beliefs, attitude, subjective norms and intention. In the theory of planned behavior, attitudes toward behaviors and subjective norms influence people's behavior (Ajzen \& Fishbein, 1980).

Customer satisfaction has been a central conception in marketing literature and is a pivotal goal of all business activities (Adams, 1965; Oliver \& Swan, 1989). Oliver (1997) described customer loyalty as the commitment of the customer to repurchase a product or service in the future. Recently, companies have faced difficulties as they move from a product and sales philosophy to a marketing philosophy, which gives a company a better chance of outperforming its competition (Kotler, 2000). Customer loyalty is defined as a deep commitment when customers prefer to re-buy products or re-use services, and it occurs even though there is a visible effect on the part of other businesses to make customer switch (Kotler, 2002; Oliver, 1997). Loy alty also refers to customer retention that optimizes the profitability of a business, in which the cost of obtaining new customers is higher than the cost of retaining existing customers (Anjelova \& Zekiri, 2011). Fornell (1992) identifies that the perception of a potential customer is usually affected by the values of services or products according to satisfaction type and values. The relationship between satisfaction and loyalty is connected with the potential growth of the business. Chaudhuri (1999) argued that customer loyalty is the most competitive asset in many sectors, considering that customer retention could lead towards long-term and profitable relationships with consumers (Tseng 2007). For the business sector, the relationship between company and customer loyalty is regarded as one of the most important management strategies (Peng \& Wang, 2006).

\section{HYPOTHES IS DEVELOPMENT}

Previous research has addressed that justice dimensions including procedural justice, interactional justice, and distributive justice are crucial factors in investigating customer satisfaction and loyalty (Seiders \& Berry, 1998; Goodwin \& Ross, 1992). With respect to perceived values, price is regarded as one of the elements that highly affect the consumer behavior, and satisfaction, and reliability (Lichtenstein, Ridgway, and Netemeyer, 1993; Grewal, Monroe, \& Krishannan, 1998). Perceived trust has also been a critical factor in terms of productive and cohesive functions (Stolle, 2002). Perceived experiences are also a signific ant variable in regard to perceived values to affect the brand image of corporations (Nguyen \& Leblanc, 2001). Taking the above considerations into account, this study examines the effect of justice dimensions of customer and their perceived values such as price, trust, and experience on customer satisfaction in the context of the sharing accommodation business. The proposed model of the study is presented in Figure 1, modified from previous studies (Johnson et al., 2000; Blodgett, Hill, \& Tax, 1997; Oliver, 1980). This conceptual framework describes the proposed relationships among the perceptions of customers 
including justice dimensions, perceived values, intention to use, customer satisfaction, and loyalty. By applying concepts in the sharing economy context, this study added perceived values in addition to the impacts of justice dimensions on customer satisfaction. This study also classified two customer groups i.e. potential and existing users to measure the effects of justice dimensions and perceived values on customer intention to use and satisfaction.

\subsection{Effects of Awareness on Justice Dimensions and Perceived Values}

In regards to the consumer decision-making model (Roberts \& Lattin, 1991), awareness is a key variable in building consumer perception of the products and services (Ashworth \& Free, 2006). Keller (1998) mentioned that the name of the brand, including services and products, is one of the influential factors that leads to the awareness or familiarity of consumers. The higher consumer awareness is built on the brand and services, the more the brand is trusted by customers (Hoyer \& Brown, 1990). In terms of jus tice dimensions, previous research has mentioned that the dimensions are determinants of customer satisfaction and loyalty (Clemmer \& Schneider, 1996). In regard to the perceived values, Rokeach (1973) states that it is the beliefs people hold regarding the goals that they deserve. The perceived values of customers are the main issues handling various marketing activities depending on consumer awareness (Holbrook, 1994).

This study hypothesized that higher consumer awareness of the sharing economy is related to higher levels of procedural, interactional, and distributive justice perception.

H1-2a: The awareness of the sharing economy positively affects procedural justice for both potential and existing customers.

H1-2b: The awareness of the sharing economy positively affects interactional justice for both potential and existing customers.

H1-2c: The awareness of the sharing economy positively affects distributive justice for both potential and existing customers.

This study also hypothesized that higher consumer awareness of the sharing economy is related to higher levels of perceived price, trust, and experience.

H3-4a: The awareness of the sharing economy positively affects the perceived price of customers towards sharing accommodation service.

H3-4b: The awareness of the sharing economy positively affects the perceived trust of customers towards sharing accommodation service.

H3-4c: The awareness of the sharing economy positively affects the perceived experience of customers towards sharing accommodation service.

\subsection{Effects of Perceived Justice on Customer Intention and Satisfaction}

The conception of the perceived justice dimensions is regarded as fairness, rightness, and deservingness in terms of the perception of customers (Oliver, 1997). According to Seiders and Berry (1998), customers evaluate a justice dimension by comparing their perceptions of the experience they received to what they believe it should be. With respect to procedural justice, it is considered that procedural justice positively affects how people react to outcomes. Therefore, justice dimension with outcome-to-input ratios evaluates customer satisfaction in purchasing the products and services (Oliver, 1980; 1997). In terms of interactional justice, Goodwin and Ross (1992) noted that it is positively related to customer satisfaction in the context of service failure. Interactional justice, focusing on service management, is one of the crucial factors in predicting customer satisfaction and loyalty (Grönroos, 1994). In distributive justice, the basic concept is that consumers in such a way as to maximize gains and minimize losses (Adams, 1965). It is also depicted as the allocation of costs and benefits in terms of exchange relationships (Smith, Bolton, \& Wagner, 1999). Clemmer and Schneider (1996) examined the effects of procedural justice, interactional 
justice, and distributive justice on customer satisfaction. This study hypothesized that the effects of justice dimension affects the intention to use on the part of potential customer (hypotheses 5a-c) and satisfaction for an existing customer (hypotheses 6a-c).

H5-6a: Procedural justice on sharing accommodation affects the intention to use for potential consumers and satisfaction for existing customers.

H5-6b: Interactional justice on sharing accommodation affects the intention to use for potential consumers and satisfaction for existing customers.

H5-6c: Distributive Justice on sharing accommodation affects the intention to for potential consumers and satisfaction for existing customers.

\subsection{Effects of Perceived Values on Potential Customer Intention and Satisfaction}

Heinonen (2004) described perceived values as an overall assessment of the usefulness based on the consumer perceptions of what is received and what is given. Consumers' perceived values are significantly related to their attitude, satisfaction, and loyalty, and this also in turn affects corporations' profit (Khalifa, 2004). In terms of the price value, research has stated that the price is a crucial instrument for affecting consumer behavior and satisfaction (Lichtenstein, Ridgway, and Netemeyer, 1993; Grewal, Monroe, \& Krishannan, 1998). Trust is another variable to examine in determining customer intention and satisfaction (Stolle, 2002). Stolle (2002) also maintained that perceived trust could play a significant role in relationships between individuals, communities, regions, and nations. Previous studies argued that trust is, in particular, one of the essential elements in e-commerce management (Kim, Ferrin, \& Rao, 2003). Experience as the perceived values of customers is a crucial factor affecting the brand images of corporations (Nguyen \& Leblanc, 2001). Recently, PwC (2015) found that consumers are willing to use sharing economy services that include unique and attractive experiences. This study hypothesized that effects of perceived values affects the intention to use for a potential customer (hypotheses 7a-c) and satisfaction for an existing customer (hypotheses 8a-c).

H7-8a: Perceived price of sharing accommodation affects the intention to use for potential and customers satisfaction for existing customers.

H7-8b: Perceived trust in sharing accommodation affects the intention to use for potential and satisfaction for existing customers.

H7-8c: Perceived experience of sharing accommodation affects the intention to use for potential and satisfaction for existing customers.

\subsection{Effects of Customer Satisfaction on Customer Loyalty}

Customer satisfaction has been a crucial conception in marketing literature and is a pivotal goal of all business activities (Adams, 1965; Oliver \& Swan, 1989). Oliver (1997) also depicted customer loyalty as the commitment of the customer to repurchase the product or service in the future. In terms of loyalty issues based on a psychological approach, loyalty is a positive attitude toward the firm and provider as they pursue maintaining the relationship over the long term (Oliver, 1999). Zeithaml (1988) mentioned that there is considerable research on satisfaction's effect on loyalty in terms of perceptions of price, service quality and values. Thus, positive evaluation of products or services becomes the main reason to continue the relationship with the companies (Chen \& Wang, 2009). This study hypothesized effects of satisfaction on loyalty for sharing accommodation.

H9: Higher satisfaction with sharing accommodation is related to higher levels of customer loyalty. 


\section{METHODOLOGY}

This study examined the impact of justice dimensions and perceived values on customer satisfaction and loyalty in the context of the sharing economy focused on accommodation services. The study conducted an online survey to measure consumer satisfaction and loyalty towards the sharing accommodation business. The study examines the effect of procedural justice, interactional justice, and distributive justice as well as perceived price, trust, and experience. The study was distributed to 285 people, and a total of 233 respondents completed the survey, with a response rate of 81.7 percent. Among the respondents, existing customers were 153 people and potential customers were 80 people. The questionnaire in the survey mainly consists of the parts to ask basic opinions based on attit udes and satisfaction toward the sharing accommodation business. The survey employed a 7-point Likert scale where 1 indicates "strongly disagree" and 7 indicates "strongly agree." The developed survey was based on scales from previous studies (Cho, 2012; Oliver, 1980; Blodgett, Hill, Tax, 1997; Blodgett, Granbois, and Walters, 1993). This study developed a questionnaire for the concepts of justice dimensions and perceived values such as price, trust, and experience. In order to test the construct reliability of variables for a multi-item scale, Cronbach's alpha was conducted for each major element. The values of Cronbach's alpha were 0.83 for interactional justice, 0.82 for distributive justice, and 0.85 for procedural justice based on potential customers. Based on existing customers, Cronbach's alpha values were 0.82 for interactional justice, 0.81 for distributive justice, and 0.83 for procedural justice. In addition, the Cronbach's values of perceived values were 0.77 for trust, 0.72 for experience and price based on potential customers. With regards to existing customers, Cronbach's alpha values were 0.77 for perceived price, 0.71 for trust, and 0.77 for experience. This study conducted correlation analysis and found that there is no correlation $(r=0.000)$ among justice dimensions and also perceived values.

\section{DATA ANALYSIS}

Of the 233 respondents, $56 \%$ were female and $44 \%$ were male; $1 \%$ were under 19 years old, $12 \%$ were $20-24$ years old, $43 \%$ were $25-29$ years old, $30 \%$ were $30-34$ years old, $10 \%$ were $35-39$ years old, and $4 \%$ were $40-44$ years old. In terms of educational background, 3\% had a high school degree or below, 66\% had a bachelor degree, and $31 \%$ had a Master's degree or higher. With regard to annual income, $8 \%$ of the respondents had an annual household income of less than $\$ 10,000,4 \%$ had annual incomes between $\$ 10,001$ and $\$ 20,000,24 \%$ had annual incomes between $\$ 20,001$ and $\$ 30,000,19 \%$ had annual incomes between $\$ 30,001$ and $\$ 40,000,10 \%$ had annual incomes between $\$ 40,001$ and $\$ 50,000$, and $4 \%$ had annual incomes between $\$ 50,001$ and $\$ 60,000$. In terms of occupation, $30 \%$ were students, $26 \%$ were businessmen, $10 \%$ were educators, and $3 \%$ owned their own businesses.

The study applied factor analysis to check the validity of the major construct. Using principal components analyses as the extraction method and Varimax rotation methods with Kaiser Normalization, the most relevant data emerged. The results of factor analysis successfully represented the major constructs with Eigen values greater than 1.00. Table 1 summarized the results of factor analysis for the justice dimensions for potential customers. 
Table 1. Component Matrix: Justice Dimensions for Sharing Accommodation of Potential Customers

\begin{tabular}{|c|c|c|c|c|}
\hline \multicolumn{2}{|r|}{ Items } & \multicolumn{3}{|c|}{ Components } \\
\hline Factors & S cale Items & 1 & 2 & 3 \\
\hline DISTRIBUTIVE 4 & $\begin{array}{l}\text { I think that I would receive the good quality of accommodation by } \\
\text { considering the cost. }\end{array}$ & .888 & & \\
\hline DISTRIBUTIVE 5 & $\begin{array}{l}\text { Overall, I think that I receive (have received) the sharing } \\
\text { accommodation service that I expected. }\end{array}$ & .885 & & \\
\hline DISTRIBUTIVE 2 & $\begin{array}{l}\text { I think that the available services from sharing accommodation are } \\
\text { fair compared to others. }\end{array}$ & .815 & & \\
\hline DISTRIBUTIVE 3 & $\begin{array}{l}\text { In terms of cost-effectiveness, I think that I would receive a } \\
\text { competent service than others. }\end{array}$ & .632 & & \\
\hline INTERACTIONAL 4 & $\begin{array}{l}\text { I think that the service from personal provider would be friendly } \\
\text { compared to using other services. }\end{array}$ & & .814 & \\
\hline INTERACTIONAL 5 & $\begin{array}{l}\text { I think that the information and explanation via sharing services are } \\
\text { enough to buy compared to other services. }\end{array}$ & & .808 & \\
\hline INTERACTIONAL 1 & $\begin{array}{l}\text { I think the contact system between user and provider is very } \\
\text { convenient. }\end{array}$ & & .797 & \\
\hline INTERACTIONAL 2 & $\begin{array}{l}\text { I think that the interaction between user and provider is very well } \\
\text { connected. }\end{array}$ & & .711 & \\
\hline PROCEDURAL 1 & $\begin{array}{l}\text { I think that the sharing accommodation services with online are } \\
\text { easy to proceed/ easy to make reservation. }\end{array}$ & & & .872 \\
\hline PROCEDURAL 2 & $\begin{array}{l}\text { I think that offering the online room sharing services can reduce any } \\
\text { inconvenient process. }\end{array}$ & & & .864 \\
\hline PROCEDURAL 3 & $\begin{array}{l}\text { I think that I can save my time by using the sharing accommodation } \\
\text { services than other hospitalities. }\end{array}$ & & & .630 \\
\hline
\end{tabular}

The purpose of the study is not only to investigate the justice dimensions but also to examine the perceived values for both potential customers and existing customers. Therefore, the same components analysis are conducted below. The results of factor analysis show that it turned up the major elements, with Eigen values greater than 1.00. Table 2 summarized the outcome of factor analys is for perceived values for potential customers.

Table 2. Component Matrix: Perceived Values for Sharing Accommodation of Potential Customers

\begin{tabular}{|c|c|c|c|c|}
\hline \multicolumn{2}{|r|}{ Items } & \multicolumn{3}{|c|}{ Components } \\
\hline Factors & S cale Items & 1 & 2 & 3 \\
\hline TRUST 2 & I think that personal transaction sy stem $(\mathrm{P} 2 \mathrm{P})$ is quite credible. & .844 & & \\
\hline TRUST 3 & $\begin{array}{l}\text { I think I would not worry about private information exposure in } \\
\text { using sharing accommodation services. }\end{array}$ & .841 & & \\
\hline TRUST 4 & $\begin{array}{l}\text { I think that the legal system dealing with sharing business is fairly } \\
\text { safe. }\end{array}$ & .755 & & \\
\hline TRUST 1 & $\begin{array}{l}\text { I think that it is credible information that the provider gives to } \\
\text { consumer. }\end{array}$ & .753 & & \\
\hline EXPERIENCE 3 & $\begin{array}{l}\text { By using the sharing accommodation services, I could not only } \\
\text { sharing the spaces but also sharing the cultural exp erience in other } \\
\text { countries. }\end{array}$ & & .842 & \\
\hline EXPERIENCE 2 & $\begin{array}{l}\text { By using the sharing accommodation service, I could have local } \\
\text { experiences in other countries. }\end{array}$ & & .826 & \\
\hline EXPERIENCE 1 & $\begin{array}{l}\text { By using the sharing accommodation service, I could make unique } \\
\text { stay ing experience compared to others. }\end{array}$ & & .687 & \\
\hline PRICE 2 & $\begin{array}{l}\text { I think that I would reduce the travel cost by using sharing } \\
\text { accommodation services. }\end{array}$ & & & .805 \\
\hline PRICE 1 & $\begin{array}{l}\text { I think that the price from sharing accommodation is fair / reasonable } \\
\text { compared to other services. (i.e., Hotel, Motel, Guest house, etc.) }\end{array}$ & & & .773 \\
\hline PRICE 4 & $\begin{array}{l}\text { Overall, I am (or will be) satisfied with the price of sharing } \\
\text { accommodation services. }\end{array}$ & & & .590 \\
\hline
\end{tabular}


By using the equivalent analysis, Table 3 and Table 4 provide the results of factor analysis for both justice dimensions and perceived values for existing customers.

Table 3. Component Matrix: Justice Dimensions for Sharing Accommodation of Existing Customers

\begin{tabular}{|c|c|c|c|c|}
\hline \multicolumn{2}{|r|}{ Items } & \multicolumn{3}{|c|}{ Components } \\
\hline Factors & S cale Items & 1 & 2 & 3 \\
\hline PROCERUDAL 5 & $\begin{array}{l}\text { I think that overall transaction of sharing accommodation is well } \\
\text { proceeded. }\end{array}$ & .760 & & \\
\hline PROCERUDAL 4 & $\begin{array}{l}\text { I think that sharing accommodation service has clear and efficient } \\
\text { procedure compared to offline services. }\end{array}$ & .753 & & \\
\hline PROCERUDAL 7 & $\begin{array}{l}\text { I think that the refund system of sharing accommodation services is } \\
\text { well organized. }\end{array}$ & .727 & & \\
\hline PROCERUDAL 6 & $\begin{array}{l}\text { I think that overall information processing activities such as } \\
\text { providing information of credit card and mobile phone numbers are } \\
\text { very safely processed. }\end{array}$ & .669 & & \\
\hline PROCERUDAL 8 & $\begin{array}{l}\text { Overall, I think that procedure offered by sharing accommodation } \\
\text { services meets my expectation. }\end{array}$ & .643 & & \\
\hline DISTRIBUTIVE 5 & $\begin{array}{l}\text { Overall, I think that I receive(have received) the sharing } \\
\text { accommodation service than I exp ected. }\end{array}$ & & .799 & \\
\hline DISTRIBUTIVE 3 & $\begin{array}{l}\text { In terms of cost-effectiveness, I think that I would receive a } \\
\text { competent service than others. }\end{array}$ & & .766 & \\
\hline DISTRIBUTIVE 2 & $\begin{array}{l}\text { I think that the available services from sharing accommodation are } \\
\text { fair compared to others. }\end{array}$ & & .727 & \\
\hline DISTRIBUTIVE 4 & $\begin{array}{l}\text { I think that I would receive the good quality of accommodation by } \\
\text { considering the cost. }\end{array}$ & & .648 & \\
\hline INTERACTIONAL 2 & $\begin{array}{l}\text { I think that the interaction between user and provider is very well } \\
\text { connected. }\end{array}$ & & & .860 \\
\hline INTERACTIONAL 1 & $\begin{array}{l}\text { I think the contact system between user and provider is very } \\
\text { convenient. }\end{array}$ & & & .762 \\
\hline INTERACTIONAL 3 & $\begin{array}{l}\text { I think that the review system for stay ing experience is very help ful } \\
\text { for future consumers. }\end{array}$ & & & .676 \\
\hline INTERACTIONAL 6 & $\begin{array}{l}\text { I think that sharing services are able to search very useful } \\
\text { accommodation information. }\end{array}$ & & & .589 \\
\hline
\end{tabular}

Table 4. Component Matrix: Perceived Values for Sharing Accommodation of Existing Customers

\begin{tabular}{|c|c|c|c|c|}
\hline \multicolumn{2}{|r|}{ Items } & \multicolumn{3}{|c|}{ Components } \\
\hline Factors & $\begin{array}{l}\text { S cale Items } \\
\end{array}$ & 1 & 2 & 3 \\
\hline PRICE 2 & $\begin{array}{l}\text { I think that I would reduce the travel cost by using sharing } \\
\text { accommodation services. }\end{array}$ & .738 & & \\
\hline PRICE 1 & $\begin{array}{l}\text { I think that the price from sharing accommodation is fair/reasonable } \\
\text { compared to other services. (e.g., Hotel, Motel, Guest house, etc.) }\end{array}$ & .717 & & \\
\hline PRICE 4 & $\begin{array}{l}\text { Overall, I am (or will be) satisfied with the price of sharing } \\
\text { accommodation services. }\end{array}$ & .714 & & \\
\hline EXPERIENCE 3 & $\begin{array}{l}\text { By using the sharing accommodation services, I could not only } \\
\text { sharing the spaces but also sharing the cultural experience in other } \\
\text { countries. }\end{array}$ & & .814 & \\
\hline EXPERIENCE 1 & $\begin{array}{l}\text { By using the sharing accommodation services, I could make unique } \\
\text { stay ing exp erience compared to others. }\end{array}$ & & .783 & \\
\hline EXPERIENCE 2 & $\begin{array}{l}\text { By using the sharing accommodation service, I could make local } \\
\text { experience with other countries. }\end{array}$ & & .745 & \\
\hline TRUST 3 & $\begin{array}{l}\text { I think I would not worry about private information exposure in } \\
\text { using sharing accommodation services. }\end{array}$ & & & .847 \\
\hline TRUST 4 & $\begin{array}{l}\text { I think that the legal system dealing with sharing business is fairly } \\
\text { safe. }\end{array}$ & & & .734 \\
\hline TRUST 2 & I think that personal transaction system $(\mathrm{P} 2 \mathrm{P})$ is quite credible. & & & .598 \\
\hline
\end{tabular}


In order to test the hypotheses, regression analysis was conducted using factor scores. Table 5 and 6 provide the results of regression analysis for the effects of awareness on justice dimensions for both potential and existing customers. According to Table 5 and 6, the results of the ANOVA in the case of effects of the awareness on interactional justice of potential customers in sharing economy find the models significant at the .1 level with $F=$ 2.847 ( $r$-square $=.036)$; in the case of effects of the awareness on procedural justice of existing customers in sharing economy find the models significant at the .01 level with $F=14.870$ ( $r$-square $=.095)$; and in the case of effects of the awareness on interactional justice of existing customers in sharing economy find the models significant at the .05 level with $F=7.654$ ( $r$-square $=.051$ ). Therefore, Hypotheses H1b, H2a, and H2b were accepted; whereas Hypotheses H1a, H1c, and $\mathrm{H} 2 \mathrm{c}$ were rejected. The results show that the awareness of sharing economy significantly affects interactional justice of potential customers; procedural justice and interactional justice of existing customers.

Table 5. Effects of the Awareness on Justice Dimension of Potential Customers in Sharing Accommodation

\begin{tabular}{|c|c|}
\hline Variable (Independent $\rightarrow$ dependent) & $\begin{array}{c}\text { Standardized Coefficient } \\
\text { (t-value-Sig) }\end{array}$ \\
\hline Awareness $\rightarrow$ Procedural Justice(H1a) & $\begin{array}{c}0.055 \\
(0.484)\end{array}$ \\
\hline Awareness $\rightarrow$ Interactional Justice (H1b) & $\begin{array}{l}0.190 \\
(1.687)^{*}\end{array}$ \\
\hline Awareness $\rightarrow$ Distributive Justice (H1c) & $\begin{array}{c}0.036 \\
(0.313)\end{array}$ \\
\hline
\end{tabular}

Table 6. Effects of the Awareness on Justice Dimension of Existing Customers in Sharing Accommodation

\begin{tabular}{l|c}
\hline \multicolumn{1}{c}{ Variable (Independent $\rightarrow$ dependent) } & $\begin{array}{c}\text { Standardized Coefficient } \\
\text { (t-value-S ig) }\end{array}$ \\
\hline Awareness $\rightarrow$ Procedural Justice (H2a) & 0.309 \\
$(3.856)^{* * *}$
\end{tabular}

$* * *$ Significant at 0.01 level (2-tailed)

** Significant at 0.05 level (2-tailed).

Also, Table 7 and 8 show the outcomes of regression analysis for effects of the awareness on perceived values for both potential and existing customers. With regard to Table 7 and 8, the results of the ANOVA in the case of effects of the awareness on perceived price of existing customers in sharing economy find the models significant at the .05 level with $F=5.069$ ( $r$-square $=.034$ ) and perceived experience of existing customers in sharing economy find the models significant at the .05 level with $F=8.485$ ( $r$-square $=.055)$. Therefore, Hypotheses H4a and H4c were accepted, while other hypotheses $\mathrm{H} 3 \mathrm{a}, \mathrm{H} 3 \mathrm{~b}, \mathrm{H} 3 \mathrm{c}$, and $\mathrm{H} 4 \mathrm{c}$ for the effects of awareness on perceived values were rejected. The results show that the awareness of sharing economy significantly affects the perceived price and experience of existing customers.

Table 7. Effects of the Awareness on Perceived Values of Potential Customers in Sharing Accommodation

\begin{tabular}{l|c}
\hline \multicolumn{1}{c|}{ Variable (Independent $\rightarrow$ dependent) } & $\begin{array}{c}\text { StandardizedCoefficient } \\
\text { (t-value-Sig) }\end{array}$ \\
\hline Awareness $\rightarrow$ Perceived price (H3a) & 0.127 \\
& $(1.124)$ \\
\hline \multirow{2}{*}{ Awareness $\rightarrow$ Perceived trust $(\mathrm{H} 3 \mathrm{~b})$} & 0.121 \\
& $(1.072)$ \\
\hline \multirow{2}{*}{ Awareness $\rightarrow$ Perceived experience $(\mathrm{H} 3 \mathrm{c})$} & 0.062 \\
\end{tabular}


Table 8. Effects of the Awareness on Perceived Values of Existing Customers in Sharing Accommodation

\begin{tabular}{l|c}
\multicolumn{1}{c|}{ Variable (Independent $\rightarrow$ dependent) } & $\begin{array}{c}\text { StandardizedCoefficient } \\
\text { (t-value-Sig) }\end{array}$ \\
\hline Awareness $\rightarrow$ Perceived price (H4a) & 0.183 \\
$(2.251)^{* *}$
\end{tabular}

This study, then, conducted regression analysis for the relationship between justice dimensions of potential customers and their intention, shown in Table 9. The results of the ANOVA in the case of effects of procedural justice on intention of potential customers find the models significant at the level of .05 with $F=6.001$ ( $r$-square $=$ $.073)$; and in the case of effects of distributive justice on intention of potential customers find the models significant at the level of .01 with $F=7.887$ ( $r$-square = .094). Based on the findings, hypothesis H5a and H5c were accepted, but hypotheses $\mathrm{H} 5 \mathrm{~b}$ were rejected. The study also examined the effects of justice dimensions on the satisfaction of existing customers in the sharing accommodation sector. With regard to Table 10, The results of the ANOVA in the case of effects of procedural justice on satisfaction of existing customers find the models significant at the level of .01 with $F=25.592$ ( $r$-square $=.160$ ); in the case of effects of interactional justice on satisfaction of existing customers find the models significant at the level of .01 with $F=17.956$ ( $r$-square $=.118$ ); and in the case of effects of distributive justice on satisfaction of existing customers find the models significant at the level of .01 with $F=$ 15.429 (r-square = .103). Therefore, hypotheses H6a, H6b, and H6c were significantly accepted. The findings explain that the justice dimensions of procedural justice, interactional justice, and dis tributive justice all significantly affect the satisfaction level of existing customers with the sharing accommodation sector.

Table 9. Effects of Justice Dimension on Intention of Potential Customers

\begin{tabular}{l|c}
\multicolumn{1}{c}{ Variable (Independent $\rightarrow$ dependent) } & $\begin{array}{c}\text { Standardized Coefficient } \\
\text { (t-value-Sig) }\end{array}$ \\
\hline Procedural Justice $\rightarrow$ Intention (H5a) & 0.271 \\
& $(2.450)^{* *}$ \\
\hline Interactional Justice $\rightarrow$ Intention (H5b) & 0.115 \\
& $(1.006)$ \\
\hline Distributive Justice $\rightarrow$ Intention (H5c) & 0.307 \\
\hline$* *$ Significant at 0.05 level $(2$-tailed) & $(2.808)^{* * *}$ \\
\hline
\end{tabular}

** Significant at 0.05 level (2-tailed).

$* * *$ Significant at 0.01 level (2-tailed).

Table 10. Effects of Justice Dimension on Satisfaction of Existing Customers

\begin{tabular}{l|c}
\multicolumn{1}{c|}{ Variable (Independent $\rightarrow$ dependent) } & $\begin{array}{c}\text { Standardized Coefficient } \\
\text { (t-value-Sig) }\end{array}$ \\
\hline Procedural Justice $\rightarrow$ Satisfaction (H6a) & 0.400 \\
& $(5.509)^{* * *}$ \\
\hline Interactional Justice $\rightarrow$ Satisfaction (H6b) & 0.344 \\
$(4.237)^{* * *}$
\end{tabular}

With respect to perceived justice, the study examined the effects of the perceived values of potential customers and their intention to use a sharing accommodation service. The results of regression analyses are shown in Table 11. The results of the ANOVA in the case of effects of perceived price on intention of potential customers find the models significant at the level of .01 with $F=7.024$ ( $r$-square $=.084$ ); and in the case of effects of perceived trust on intention of potential customers find the models significant at the level of .01 with $F=7.011$ ( $r$-square $=.083$ ); and in the case of effects of perceived experience on intention of potential customers find the models significant at the level of .01 with $F=40.565$ ( $r$-square = .345). Based on the findings, hypotheses H7a, H7b, and H7c were 
accepted. In other words, three perceived values of sharing accommodation significantly affect the intention to use for potential customer.

Table 11. Effects of the Perceived Values on Intention of Potential Customers

\begin{tabular}{l|c}
\multicolumn{1}{c|}{ Variable (Independent $\rightarrow$ dependent) } & $\begin{array}{c}\text { StandardizedCoefficient } \\
\text { (t-value-Sig) }\end{array}$ \\
\hline Perceived price $\rightarrow$ Intention $(\mathrm{H} 7 \mathrm{a})$ & 0.289 \\
$(2.650)^{* * *}$
\end{tabular}

With regard to the perceived values, the same analysis is conducted focusing on existing customers. The results of the ANOVA in the case of effects of perceived price on satisfaction of existing customers find the models significant at the level of .01 with $F=23.777$ ( $r$-square $=.146$ ); in the case of effects of perceived trust on satisfaction of existing customers find the models significant at the level of .01 with $F=23.448$ ( $r$-square $=.144)$; and in the case of effects of perceived experience on satisfaction of existing customers find the models significant at the level of .01 with $F=19.781$ ( $r$-square $=.125$ ). Table 12 shows that the results of multiple regression analysis for the effects of three perceived values on the satisfaction of existing customers. Overall, the results of ANOVA find the models significant at the level of .01 with $F=21.526$ ( $r$-square $=.400)$. Based on the findings, hypotheses H8a, $\mathrm{H} 8 \mathrm{~b}$, and H8c were accepted, which demonstrates that perceived values of price, trust, and experience significantly affect the satisfaction of existing customers in the context of the sharing accommodation sector.

Table 12. Effects of the Perceived Values on Satisfaction of Existing Customers

\begin{tabular}{l|c}
\hline \multicolumn{1}{c|}{ Variable (Independent $\rightarrow$ dependent) } & $\begin{array}{c}\text { StandardizedCoefficient } \\
\text { (t-value-Sig) }\end{array}$ \\
\hline Perceived price $\rightarrow$ Satisfaction (H8a) & 0.382 \\
& $(4.876)^{* * *}$ \\
\hline \multirow{2}{*}{ Perceived trust $\rightarrow$ Satisfaction (H8b) } & 0.380 \\
& $(4.842)^{* * *}$ \\
\hline \multirow{2}{*}{ Perceived experience $\rightarrow$ Satisfaction (H8c) } & 0.353 \\
\end{tabular}

$* * *$ Significant at 0.01 level (2-tailed).

The study also examined the effects of satisfaction on customer loyalty to the sharing accommodation. Table 13 provides the results of regression analyses. The results of the ANOVA find the models significant at the .01 level with $F=137.530$ ( $r$-square $=.489$ ). Therefore, hypothesis $\mathrm{H} 7$ was accepted, proving that higher levels of satisfaction with sharing accommodation services were as sociated with a higher level of customer loyalty.

Table 13. Effects of the Satisfaction on Loy alty of Customers in Sharing Accommodation

\begin{tabular}{l|c}
\multicolumn{1}{c}{ Variable (Independent $\rightarrow$ dependent) } & $\begin{array}{c}\text { Standardized Coefficient } \\
\text { (t-value-Sig) }\end{array}$ \\
\hline Satisfaction $\rightarrow$ Loyalty (H9) & 0.699 \\
$(11.727)^{* * *}$
\end{tabular}

\section{CONCLUSION}

As the sharing economy is now in its embryonic stage, there has been little research on the relevant relationships such as that between perception of customers and satisfaction. Based on such considerations, the main purpose of the study is to examine the effect of justice dimensions of customers and perceived values such as price, trust, and experience on customer satisfaction and loyalty in the field of sharing accommodation services. The results of the study find that the justice dimension and perceived values are valid and significant for measuring customer satisfaction with and loyalty to sharing accommodation services. Procedural justice and distributive justice were 
significant dimensions to influence customer intention for potential customers, whereas, all dimensions of procedural, interactional, and distributive justice were significant in affecting the satisfaction of existing customers. With regard to the perceived values, all effects of price, trust and experience were significant for potential consumers as well as the same effects of price, trust, and experience were all significant factors for existing customers. In particular, for both groups, the experience was most influential variable in leading to satisfaction and loyalty. Regarding the issue of satisfaction, this study also finds that higher levels of satisfaction lead to higher levels of loyalty in the field of sharing accommodation.

Based on the results of the analyses, the study demonstrates a few findings: i) existing and potential customers have different perceptions of the sharing economy, which lead to different levels of intention, satis faction, and loyalty; ii) perceived values of price, trust, and experience are all regarded as a significant variable for both existing and potential consumers; and iii) existing customers significantly consider their perception of justice and values with regard to their levels of satisfaction and loyalty in the context of sharing accommodation. Additionally, among the potential customers, this study found that possible customers recognize the effects of procedural and distributive justice, whereas there is lack of perception for interactional justice. The reason why potential customers are not aware of the interactional justice seems that most people who have not used sharing accommodation service before do not recognize the advantages of informative and interactive processes such as using the sharing application services or ways of searching the room. Also, among the existing customers, this study found that more than half of the respondents have experienced the sharing economy for between one and three years, and $20 \%$ of the respondents have experienced it within less than one year. These findings show that consumption based on the sharing economy has made sharp gains in recent years. No less significant is the fact that based on perceived trust, more than $58 \%$ of respondents answer that laws and regulations concerning sharing accommodation businesses need to be more favorable. These findings suggest that sharing accommodations are still subject to trust and safety issues of customers, as well as those of stakeholders in the community, city, and other nations.

The results of this study pay special attention to the theoretical implications. The study aims to evaluate the sharing economy as a contemporary business platform by examining various perceptions of customers. Recently, there has been considerable research on the sharing economy, but only few studies focusing on customers. In addition, unlike previous studies, this research considers justice dimensions with perceived values to explain customer satisfaction. This study divides these perceived values into factors of price, trust, and experience which are regarded as critical elements affecting customer satisfaction and loyalty.

This study has political implications as well. Since sharing economy platforms have become popular with both customers and entrepreneurs, government has been dealing with this economic change. Throughout the study, it discovers a few findings that can shed light on policy implications of sharing accommodation services. First, since sharing accommodation system gives consumer the local flavor that is very attractive and different from any other hospitality services (PwC, 2015), it also remains a few challenges of government and legal issues in developing sharing business model. Sharing accommodation platform is relatively in early stage, it, unlike other hospitality services, is able to revitalize regional economy. Airbnb evaluates that they make positive impacts on consumers, local businesses, and tourism industry (2015). Therefore, government should positively contemplate the emerging issues. The other issue is that there are more than half respondents who recognize the sharing accommodation business deals with trust and safety is sues. Building trust is a significant challenge for both government and sharing accommodation businesses. Especially, perceived trust has become much crucial issues when it comes to the Ebusiness platform unlike other traditional business system (Grabosky, 2001). Policy makers deliberately think of the way of constructing reliability between customers, businesses, and government. In order to overcome this new challenge in collaborative economy, government needs to consider the appropriate role in the markets, and to adjust prudent approaches to alleviate regulations.

This study also provides managerial implications. Traditionally, the consideration of justice dimensions has been regarded as a management strategy to increase customer satisfaction (Clemmer \& Schneider, 1996). Nonetheless, few studies have tried to combine justice dimensions with perceived values of customers. In order to take long-term perspective on strategic management, diverse studies need to be conducted focusing on subjective percep tions of customers such as price, trust, and experience. With respect to the collaborative economy, the study finds that, unlike other sharing businesses, sharing accommodation services take advantage of the cultural experience. With the 
consideration of the perception of experiences, it is considered to be sharing the culture, local, city, and nationals. Considering that customers prefer to have unique experiences, sharing accommodation services not only rent rooms in a house, but also can provide an entire apartment, pensions, and cultural spaces (Airbnb, 2015). Utilizing these advantages of sharing accommodation services, diverse studies of sharing accommodation can serve as guidelines for these new enterprises to become sustainable in the long term.

Although the present findings have several implications for future research, the study has a few limitations. In terms of the survey analysis, the sample size was relatively low. In addition, a number of is sues remain to be explored. As the sharing economy is in its early stage, it needs to deal with the is sues of regulation, legis lation, and conflict with the traditional market system. Also, sharing economy platform has diverged regarding the issues of cities, nations, and traditional businesses. Therefore, future studies should consider more deeply the cross -cultural environment for purposes of comparis on and generalizability. What remains for future research is to conduct panel data research, since consumers develop their perceptions of justice and values over time. By adjusting the dynamics of the samples, panel data analysis can observe multiple phenomena over time periods for the same groups or individuals. The study lays the foundation for future work on the distinction between potential and existing cust omers as well as the relationship between the level of satisfaction and the impact of the sharing business. Although the present study offered an initial contribution concerning the issues of consumer' perception on sharing accommodation services, future research should focus more on the diverse perceptions of customers in the field of the sharing economy.

\section{AUTHOR BIOGRAPHIES}

Kim, Bokyeong received a Master's degree from the KDI School of Public Policy and Management.

Yoon C. Cho is a professor at the KDI School of Public Policy and Management. She has publications in the Journal of Business Research, Advanced in Consumer Research, and Journal of Business Economics Research, etc.

\section{REFERENCES}

Aaker, D.A., Kumar, V. and Day, G.S. (2001), "Marketing Research (7 $7^{\text {th }}$ edition)," John Wiley and Son Inc, New York.

Adams, J.S. (1965), "Inequity in Social Exchange, L Berkowits, L. (Ed.), Advances in Experimental Social Psychology," Academic Press New York, 2. 267-299.

Agarwal, S. and Teas, R.K. (2002) “Cross-National Applicability of a Perceived Quality Model,” Journal of Product and Brand Management, 11(4-5), 213-36.

Anjelova, Biljana and Zekiri, Jusuf (2011), "Measuring Customer Satisfaction with Service Quality Using American Customer Satisfaction Model(ACSI Model)," International Journal of Academic Research in Business and Social Sciences, 1(3), 232- 258.

Ajzen, I. and Fishbein, M.(1980), Understanding Attitudes and Predicting Social Behavior, Prentice Hall, New York.

Allen, Darcy and Berg, Chris (2014), "The Sharing Economy: How Over-Regulation Could Destroy an Economic Revolution," Institute of Public Affairs.

Andaleeb, Syed Saad (1992), "The Trust Concept: Research Issues for Channel of Distribution," Research in Marketing, 11, 134.

Aquise, Xavier de Lecaros (2014), "The Rise of Collaborative Consumption and the Experience Economy," The Guardian, January.

Ashworth, L. and Free, C. (2006), "Marketing Data veillance and Digital Privacy: Using Theories of Justice to Understand Consumers' Online Privacy Concerns,” Journal of Business Ethics, 67, 107-123.

Babin, B.J., Darden, W.R. and Griffin, M. (1994), "Work and/or Fun: Measuring Hedonic and Utilitarian Shopping," Journal of Consumer Research, 20(4), 644-56.

Belk, Russell (2007), "Why Not Share Rather Than Own?" The Annals of the American Academy of Political and Social Science, 611, 126-140.

Benkler, Yochai. (2004), "Sharing Nicely: on Shareable Goods and the Emergence of Sharing as a Modality of Economic Production," Yale Law Journal, 114, 273-358.

Benkler, Yochai (2002), "Coase's Penguin, or, Linux and The Nature of the Firm," The Yale Law Journal, 112.

Blodgett, Jeffrey G., Donna J. Hill, and Stephen S. Tax (1997), “The Effects of Distributive, Procedural, and Interactional Justice on Post-Complaint Behavior," Journal of Retailing, 73(2), 185-210.

, Granbois, D. H, and Walters R. (1993), “The effects of Perceived Justice on Negative Word-of-Mouth and Repatronage

Intentions," Journal of Retailing, 69, 399-428.

Botsman, R (2010), "The Case for Collaborative Consumption," Video file retrieved from 
http://www.ted.com/talks/rachel_botsman_the_case_for_collaborativeconsumption.html/, 2010.

Botsman, R. (2011), "Why Do We All Own a Lawmaker?," Audio file retrieved from http://www.bbc.co.uk/iplayer/episode/p00gdb3r/One_Planet_Archive_Why_do_we_all_own_a_lawmaker/.

Botsman, R. (2013). The SharingEconomy Lacks A Shared Definition. Retrieved from http://www.fastcoexist.com/3022028/thesharing-economy-lacks-a-shared-definition

Campbell, M. C. (1999). "Why Did You Do That? The Important Role of Inferred Motive inPerceptions of Price Fairness," Journal of Product and Brand Management, 8(2), 145-152.

Campbell, M.C. (2007). "Says who?" How the source of price information and affect influence perceived price (un)fairness. Journal of Marketing Research, 44(2), 261-271.

Chaudhuri, A. (1999), “Does Brand Loyalty Mediate Brand Equity Outcomes?” Journal of Marketing Theory and Practice, Vol. 7, No. 2, pp. 136-145, 1999.

Chen, M.F., \& Wang, L. H. (2009), "The moderating role of switching barriers on customer loyalty in the Life insurance industry," The Service Industry Journal, 29, 1105- 1123.

Chiu, C.M., Lin, H.Y., Sun, S.Y. and Hsu, M.H. (2009), “Understanding Customers Loyalty Intentions toward Online Shopping: an Integration of Technology Acceptance Model and Fairness Theory," Behavior and Information Technology, 28(4), 347-360.

Cho Y. (2012), “The Effects of Customer Dissatisfaction on Switching Behavior in the Service Sector," Journal of Business and Economic Research, 2012.

Clemmer, Elizabeth C. and Benjamin Schneider (1993), "Managing Customer Dissatisfaction with Waiting: Apply ing SocialPsychological Theory in a Service Setting," Advances in Services Marketing and Management," 2, 213-29.

Cohen, C.Y. and Spector, P.E. (2001), “The Role of Justice in Organizations: a Meta-analy sis," Organizational Behavior and Human Decision Processes, 86(2), 278-321.

Cronin, J. J., Brady, M. K., and Hult, G. T.M.(2000), “Assessingthe Effects of Quality, Value, and Customer Satisfaction on Consumer Behavioral Intentions in Service Environments," Journal of Retailing, 76(2), 193-218.

Cropanzano, R., Rupp, D. E., Mohler, C. J., \& Schminke, M. (2001), “Three Roads to Organizational Justice,” G. Ferris (Ed.), Research in Personnel and Human Resources Management, 20, 1-113.

Cusumano, Michael A. (2015), "Technology Strategy and Management: How Traditional Firms Must Compete in the Sharing Economy," Communications of the ACM, 58(1), 32-34.

Keller, Kevin (1998), Strategic Brand Management: Building, Measuring, and Managing Brand Equity, Prentice Hall: Upper Saddle River.

Kim, Dan J., Ferrin, Donald L., and Rao, H. Raghav R. (2003), “Trust and Satisfaction, Two Stepping Stones for Successful ECommerce Relationships: A Longitudinal Exploration," Information Systems Research.

Dick, A.S. and Basu, K. (1994), "Customer Loyalty: toward an Integrated Conceptual Framework," Journal of the Academy of Marketing Science, 22(2), 99-103.

Fornell, Claes (1992), “A National Customer Satisfaction Barometer: The Swedish Experience,” Journal of Marketing, 1-21.

Gallarza M. G. and Saura I. G. (2006), "Value Dimensions, Perceived Value, Satisfaction and Loyalty: An Investigation of University Students' Travel Behaviour," Tourism Management, 27, 437-452.

Gansky, L. (2010), The Mesh: Why the Future of Business Is Sharing, New York: Penguin Group.

Goodwin C. and Ross I. (1992), "Consumer Responses to Service Failures: Influence of Procedural and Interactional Fairness Perceptions," Journal of Business Research, 25, 149-163.

Grewal D., Monroe K.B., and Krishanan R. (1998), “The Effects of Price-comparison Advertising on Buy ers' Perceptions of Acquisition Value, Transaction Value, and Behavioral Intentions," Journal of Marketing, 62(2), 46-59.

Grönroos, Chiristian (1984), “A Service Quality Model and Its Marketing Implications,” European Journal of Marketing, 18(4), 36-45.

Grönroos, C. (1994), "From Marketing Mix to Relationship Marketing: Towards a Paradigm Shift in Marketing," Management Decision, 32, 4-20.

Hardin, Garret (1968), "The Tragedy of the Commons," American Association for the Advancement of Science, 162(3859), 12431248.

Heinonen, K. (2004), "Reconceptualizing Customer Perceived Value: The Value of Time and Place." Managing Service Quality, 14(2), 205-215.

Holbrook, M.B. (1994), “The Nature of Customer Value: An Axiology of Services in the Consumption Experience,” In R. Rust, \& R. Oliver (Eds.), Service Quality: New Directions in Theory and Practice, Thousand Oaks, CA: Sage Publications, 21-71.

Holbrook, Morris B. and Elizabeth C. Hirschman (1982), "The Experiential Aspects of Consumption: Consumer Fantasies, Feelings, and Fun," Journal of Consumer Research, 9 (September), 132-140.

Homans, B. C (1961), "Social Behavior: Its Elementary Forms," Oxford Harcourt Brace Jovanovich.

Hoyer, W. D., and Brown, S. P, (1990), "Effects of Brand Awareness on Choice for a Common, Repeat Purchase Product," Journal of Consumer Research, 17, 141-148.

Huppertz, John W., Sidney J. Arenson, and Richard H. Evans (1978), “An Application of Equity Theory to Buy er-Seller Exchange Situations," Journal of Marketing Research, 15, 250-60. 
Jacoby, J. and Jerry C. Olsen (1977), “Consumer Response to Price: An Attitudinal, Information Processing Perspective,” in Moving ahead with Attitude Research, Wind and P. Greenberg, eds. Chicago: American Marketing Association, 73-86.

Johnson, M. D., Gustafsson, A., Andreassen, T. W., Lervik, L. and Cha, J. (2001), "The Evolution and Future of National Customer Satisfaction Index Models,” Journal of Economic Psychology 22, pp. 217-245.

Khalifa, A.S. (2004), "Customer Value: A Review of Recent Literature and an Integrative Configuration," Management Decision, 42(5-6), 645-66.

Lichtenstein, Donald R,, Ridgway, Nancy M., and Netemeyer, Richard G. N. (1993), "Price Perception and Consumer Shopping Behavior: A Field Study," Journal of Marketing Research, 30(2), 234-245.

Lind, E. A. and Tyler, T. R. (1988), The Social Psychology of Procedural Justice. Plenum, New York.

Masoodul Hassan et al. (2013), "Measuring Customer Satisfaction and Loyalty through Service Fairness, Service Quality and Price Fairness Perception: An Empirical Study of Pakistan Mobile Telecommunication Sector," Journal of the Science International (Lahore), 25(4), 971-980.

Maxham, J. G. and Netemeyer, R. G. (2002), "Modeling Customer Perceptions of Complaint Handling over Time: the Effects of Perceived Justice on Satisfaction and Intent," Journal or Retailing, 78(4), 239-252.

Mizik, N. and Jacobson, R. (2003) 'Trading Off between Value Creation and Value Appropriation: The Financial Implications of Shifts in Strategic Emphasis', Journal of Marketing 67(1), 63-76.

Monroe, K.B. (1990), Ricing: Making Profitable Decisions, New York: McGraw-Hill.

Nguyen, N., and Leblanc, G. (2001). "Corporate Image and Corporate Reputation in Customers' Retention Decisions in Services," Journal of Retailing and Consumer Services, 8(4),227-236.

Oliver, R. L. (1980), “A Cognitive Model of the Antecedents and Consequences of Satisfaction Decisions, Journal of Marketing Research, 17( 4), 460-469. (1997), Satisfaction: A Behavioral Perspective on the Consumer, McGraw-Hill, Boston. (1999), "Whence Consumer Loyalty," Journal of Marketing, 63, 33-44.

and Swan J. E. (1989), "Consumer Perceptions of Interpersonal Equity and Satisfaction in Transactions: A Field Survey Approach," Journal of Marketing, 53, 21-35.

Owyang, J. (2013), “The Collaborative Economy," Altimeter Research, 1-27.

Peng L. Y., and Wang Q. (2006), "Impact of Relationship Marketing Tactics (RMTs) on Switchers and Stayers in a Competitive Service Industry," Journal of Marketing Management, 22(1), 25-59.

Poole, Wendy, L. (2007), "Organizational Justice as a Framework for Understanding Union Management Relations in Education," Canadian Journal of Education," 30(3), 725-748.

Pricewaterhouse Coopers LLP. (2015), “The Sharing Economy: Consumer Intelligent Series,” Pricewaterhouse Coopers LLP. Reichheld F. F., (1996), “The Loyalty Effect," Harvard Business School Press, Boston, Massachusetts.

Rinne, April, Lauren Anderson, Jem Bendell, Rachel Botsman, Privahini Bradoo, David Chiu, Rossanna Figuera, Kaliy a Hamlin, Kate Hampton, Pooja Jain, Jerry Michalski, James Moody, Kohei Nishiy ama, Julia Novy-Hildesley, Kristin D. Rechberger, Lucas Simons, Adam Werbach, and Peter Wurtenberger (2013), "Position Paper: Young Global Leaders Sharing Economy Working Group - Circular Economy Innovation \& New Business Models Initiative," Retrieved from http://www.slideshare.net/CollabLab/y gl-sharing-economy-position-paper-final-june-2013.

Roberts, John H. and James M. Lattin (1991), “Development and Testing of a Model of Consideration Set Composition,” Journal of Marketing Research, 28, 429-440.

Rokeach, M. (1973), The Nature of Human Values, New York: The Free Press.

Seiders K. and Berry L. L. (1998), "Service Fairness: What It Is and Why It Matters," Academy of Management Executive, 12, 820.

Sheth, J.N., Newman, B.I. and Gross, B.L. (1991), Consumption Values and Market Choices. Theory and Applications, Cincinnati, OH: South-Western Publishing Co.

Smith, A. K., Bolton, R. N., and Wagner, J. (1999). "A Model of Customer Satisfaction with Service Encounters Involving Failure and Recovery," Journal of Marketing Research, 36(3), 356-373.

Stolle, D. (2002), “Trusting Strangers - The Concept of Generalized Trust in Perspective," OZP State Institute of Science and Politics, 31(4), 397-412.

Spiteri, J.M. and Dion, P.A. (2004) 'Customer Value, Overall Satisfaction, End-User Loyalty, and Market Performance in Detail Intensive Industries', Industrial Marketing Management, 33(8), 675-87.

Stewart, K. and S. Reed (1999), “Consumer Price Index Research Series using Current Methods,” Monthly Labor Review.

Thibaut, John and Walker, Laurens, Hillsdale, N.J. (1975), "Procedural Justice: A Psychological Analy sis,” Lawrence Erlbaum Associates, 1289-1296.

Tax, S. S., Brown, S. W., and Chandrashekaran, M.(1998), “Customer Evaluations of Service Complaint Experiences: Implications for Relationship Marketing,” Journal of Marketing, 62(2), 60-76.

Tellis, G.J and Gaeth, G.J. (1990), "Best Value, Price-Seeking, and Price Aversion: The Impact of Information and Learning on Consumer Choices," Journal of Marketing, 54(2), 34-45.

Tseng, Yi Ming (2007), “The Impacts of Relationship Marketing Tactics on Relationship Quality in Service Industry,” The Business Review, Cambridge, 7(2), 310-314.

Vicente M.T, Jose M. P., Jose R., and Carolina M.(2006), "Justice Perceptions as Predictors of Customer Satisfaction: The 
Impact of Distributive, Procedural, and Interactional Justice," Journal of Applied Social Psychology, 36(1), 100-119. Walsh, Bryan (2011), "10 Ideas That Will Change the World: Today's Smart Choice: Don't Own. Share," TIME, March.

Whitlar, D.B., Geurts, M.D., Swenson, M.J. (1993), "New Product Forecasting with a Purchase Intention Survey," The Journal of Business Forecasting Methods Systems and Systems, 12(3), 1-18.

Xia, L., Monroe, K. B., and Cox, J. L. (2004), "The Price is Unfair: A Conceptual Framework of Price Fairness Perceptions," Journal of Marketing, 68, 1-15.

Xiong, L. and Liu, L. (2002), "Building Trust in Decentralized Peer-to-peer Electronic Communities," Paper presented at the Fifth International Conference on Electronic Commerce Research.

Zeithaml, V. A. (1988), "Consumer Perceptions of Price, Quality, and Value: A Means-end Model and Synthesis of Evidence," Journal of Marketing, 52(3), 2-22.

\section{ONLINE RESOURCES}

Airbnb Fact Information, www.airbnb.com Accessed Oct 1, 2015.

https://www.opendemocracy.net/transformation/adam-parsons/sharing-economy-short-introduction-to-its-political-evolution\# https://www.pwc.com/us/en/technology/publications/assets/pwc-consumer-intelligence-series-the-sharing-economy.pdf 